\title{
Law: Anthropological Aspects
}

Sally E Merry and Matthew C Canfield, New York University, New York, NY, USA

(c) 2015 Elsevier Ltd. All rights reserved.

This article is a revision of the previous edition article by S.E. Merry, volume 12, pp. 8489-8492, (c) 2001, Elsevier Ltd.

\begin{abstract}
Anthropologists approach law as a form of normative ordering that includes rules and processes. The anthropology of law has evolved significantly from viewing law as a measure of civilization and savagery to understanding law as an emergent cultural feature and form of power. Contemporary anthropologists investigate law ethnographically, by looking at disputes in spaces that lack formal legal institutions and codified law, as well as in the institutional sites where law is produced. Plural legal orders, each invested with particular modes of authority, are seen as a feature of all societies. With the growth of globalization and transnational law, anthropology has extended its scope to explore the dialectical interaction between these multiscalar forms of law.
\end{abstract}

Anthropologists approach law from a comparative perspective and examine it in social context. 'Law' refers broadly to the rules, processes, and norms that regulate social life. Although there are frequently institutionalized systems for making decisions and enforcing them, legal anthropology does not restrict its attention to formal systems of courts or to the law of the nation-state. Anthropological approaches to law examine the legal ordering of villages, bands, and urban neighborhoods places that usually lack specialized legal institutions and codified rules - as well as a wide range of institutional systems and technologies of law.

The anthropological study of law began from nineteenthcentury evolutionary theories in which the form of law revealed the stage of social development. Twentieth-century legal anthropology examines processes of resolving disputes and maintaining social order on multiple scales. While interpretive approaches differ, law is understood as a form of power, invested with particular forms of authority. Recent scholarship has examined the relationship between law and culture, with special attention to the role of language. In examining law through its broader social and normative contexts, anthropologists have focused on the legal complexity produced by intersections among plural legal orders rooted in the community, the state, and international institutions and agents.

\section{Historical Developments in the Anthropology of Law}

The great nineteenth-century theorists of social evolution understood law as a measure of civilization and savagery. In Ancient Law, Sir Henry Maine (1861) theorized that with the transformation from kin-based to territorially based societies, law shifted its normative basis from status to contract. Similarly, sociological theorists such as Émile Durkheim and Marcel Mauss suggested that law emerged from an embedded form of repressive sanctions to an instrument arranged by specialized tribunals and functionaries that serves to maintain cooperation. These early theories identified law as a key facet of civilization, raising questions about the universality of law and the different forms it may take within distinct social and cultural contexts. As British social anthropologists pioneered the ethnographic method, they took up these questions and debated the very definition of law.

During the early twentieth century, two major schools of thought developed. One school followed from the work of Bronislaw Malinowski (1926), who defined law in functional terms, identifying it with a broad range of social processes that produce social conformity through social pressure and inducement. Through his fieldwork in the Trobriand Islands, Malinowski located law within the domain of everyday life, rather than the state or other institutions. He defined law in terms of the relationships of reciprocity that he argued were a fundamental mechanism for maintaining social control. With Malinowski's definition, every society has law. Critics of this view contend that defining law as social control is too broad and includes practices such as gossip, ostracism, and shaming that are not lawlike.

A second school took a more structural approach to define law in terms of institutions, requiring socially authoritative mechanisms for enforcing rules through the imposition of sanctions. Radcliffe-Brown pioneered this perspective, defining law as "social control through the systematic application of the force of politically organized society" (1933, p. 202). Under this definition, all societies have customs and sanctions, but not all societies have law. E.A. Hoebel defined law more broadly, but also within an institutional context, as "the legitimate use of physical coercion by a socially authorized agent" (1954, p. 26). In The Cheyenne Way, Hoebel and legal scholar Karl Llewellyn developed a case-method approach to look at 'trouble cases' (1941). This early collaboration demonstrated the importance of anthropological approaches for legal scholars and other social scientists. As progressive legal scholars associated with the legal realist school critiqued formalist or positivist jurisprudence - the then-dominant paradigm among legal scholars and practitioners - they turned to anthropologists to demonstrate the cultural effects of law. Critics of this view of law, however, argue that this rule-based perspective is based on Western conceptions of law (Comaroff and Roberts, 1981, pp. 6-7).

Between the 1930s and 1960s, anthropologists sought to describe the nature of rules of whole societies. For example, Isaac Schapera attempted to develop an entire casebook of 
Tswana law based on his ethnographic research, while Leopold Pospisil sought to provide a more far-reaching universalistic definition of law based on his fieldwork with the Kapauku Papuans. Yet these scholars confronted the paradox that there were frequently discrepancies between these rules and everyday forms of behavior. Moreover, anthropologists debated the very nature of the comparative method?. While Max Gluckman argued that indigenous legal concepts processes could be translated into the terms of Western jurisprudence, Paul Bohannan countered that these terms could be understood only in reference to the total social and legal systems of which they were a part. This debate, which went to the heart of the definition of law and the nature of legal comparison, became increasingly sterile. By the 1970s, this debate was largely abandoned in favor of understanding law as a social process (see Moore, 1973; Nader, 1997).

\section{Law and Dispute Processes}

In the early 1970s, anthropologists turned to studying processes by which conflicts are handled and resolutions achieved (see Moore, 1978). Laura Nader and her students researched how litigants pursued disputes and how these disputes were resolved in a wide variety of societies (Nader and Todd, 1978). This approach used extended case study analysis and emphasized the perspective of litigants rather than judges. It broke dramatically with the earlier focus on rules and looked instead at the processes by which individuals pursued grievances. At the same time, it built on a tradition of analyzing extended case studies in the context of social relationships. For example, Max Gluckman argued that closeknit villages tended to have compromise settlement processes, while more loose-knit ones favored more adversarial processes (Gluckman, 1973). The focus on dispute processes remains a basic framework for the anthropology of law.

By the early 1980s, however, it became clear that a focus on the processes of resolving conflicts could not be separated from a consideration of rules and how they were formed. In their study of the Tswana, Comaroff and Roberts found that the meaning and relevance of rules are negotiated in disputes (1981, pp. 5-17). Arguments among disputants are framed by rules, but the content of rules is negotiated as disputes are argued and resolved (1981, p. 19). This more interactive understanding of rules and processes has proved valuable for examining the operation of law in communities as well as in more formal settings, such as courts. It led to an approach that conceptualized law as more deeply embedded within culture, as a system that was both constituted by and constructive of social meaning.

\section{Law, Culture, and Language}

The legal system of a society reflects its fundamental values and its normative order (Rosen, 1989). Geertz (1983) describes law as a form of 'local knowledge' that is 'a distinct way of imagining the real.' In developing an interpretive, comparative approach, Geertz argues that anthropological analyzes should approach law as a normative process of social representation. Law is not merely constitutive of social reality, but also reflects particular ideals of justice. To capture this dialectic, Geertz suggests that the comparative study of law should consist of the study of 'cultural translation.' In analyzing this process of translation, anthropologists have pointed out that law is essentially a language and that legal procedures are fundamentally linguistic.

Following a processual model of analyzing law, Sally Humphreys (1985) suggests that law can be studied as a form of discourse that is embedded in particular notions of power. Taking up this approach, scholars developed a focus on law and language that combines sociolinguistic analysis and law and society scholarship to look at the way that law creates meanings and exercises power through linguistic exchanges in courtrooms and other legal settings (Conley and O'Barr, 2005). This work provides a way to look at the detailed interactions that determine how the law exercises power. For example, many features of the kinds of talk that are persuasive in American courtrooms are more characteristic of male than female speakers, and of powerful rather than powerless speakers, so that male litigants in these courtrooms have an advantage (Conley and O'Barr, 2005). Analyzing the microdiscourses that take place in mediation centers, courtrooms, and other legal settings, scholars have applied insights drawn from linguistic anthropology, such as conversation analysis, to show how macrosociological relations of power are constituted through techniques such as controlling silences and suppressing arguments.

Legal language and institutions also offer avenues for resistance. In particular, the language of rights has proved a powerful framework for social justice movements, especially since the end of the Cold War. Rights talk has been central to labor movements, indigenous people's movements, the antiapartheid movement in South Africa, and movements for women's rights, to name a few examples. Local groups around the world now draw on global conceptions of human rights for inspiration. Much contemporary social justice talk and activism take place within the domain of law. Anthropologists have questioned whether the proliferation of formal rights language offers a useful form of resistance in the diverse and complex struggles that individuals and groups are engaged in to contest culturally constituted inequalities in diverse regions of the world. Merry's (2006a) investigation of the Convention to End All Forms of Discrimination against Women focused on the ways that elites translate between the vernacular language of duties and responsibilities and the global language of human rights. Although human rights must be vernacularized to effectively change relationships of power within a given society, she argues, the language of human rights nevertheless "comes with a price. Human rights promote ideas of individual autonomy, quality, choice and secularism even when these ideas differ from prevailing cultural norms" (2006a, p. 4). This work has described the deeply embedded cultural and political conceptions within legal language as well as the limits of legal language as a form of social representation (Hastrup, 2003). As the language of law is deployed within different cultural milieus, anthropologists have attended to the ways that people wrestle with the legal categories through which they must make their claims. 
Anthropologists have also drawn from linguistic anthropology to track the ways in which law serves as a particular ideology that is embedded within normative epistemologies. Elizabeth Mertz describes how the pedagogy of US law schools serves to socialize law students into a particular, 'culturally driven model of justice.' Students are systematically 'urged to pay attention more to abstract categories and legal (rather than social) contexts' that serve to cultivate the authority of textual analysis and legal form (2007, p. 5). Mertz shows while legal language and processes offer a creative system for handling disputes, they may also privilege particular cultural viewpoints over others. Similarly, Justin Richland (2008) describes how language ideologies often conflict within Hopi jurisprudence. While he too notes how legal language serves to socialize a particular population into the ideology of law, he also shows how these ideologies may be transformed over time through mutually constitutive interaction with divergent worldviews. Through close linguistic and interactional analysis within a Hopi courtroom, Richland examines the way in which Hopi judges and lawyers attempt to develop a Hopi form of jurisprudence based on 'tradition.' He suggests that Hopi law and ideas about tradition are constituted through a dialectical tension between Hopi and Anglo-American concepts of objectivity and forms of narrative.

\section{Law and Power}

The law also provides a rich vocabulary for describing and legitimating relationships of unequal power. It contributes in significant ways to the hegemony of a political system by engendering consent and fostering legitimacy for its exercise of power (see Nader, 1991). Since the 1980s, the anthropology of law has become concerned increasingly with the relationship between law and the exercise of power (see Starr and Collier, 1989). Inspired by Marxist and Foucauldian theories as well as the Critical Legal Studies Movement in law schools that argued that law reflects the interests of dominant groups rather than simply the logic of legal reasoning, anthropologists examined the way law supports relations of power in a wide range of social contexts (see Lazarus-Black and Hirsch, 1994). However, this research also demonstrated how law challenges dominant groups. It showed law to be a double-edged sword, expressing the rules and sanctioning authority of established political authorities and at the same time offering opportunities and justifications for resisting political authorities.

For example, social movements that call on civil rights, such as the US civil rights movement against racial discrimination in the 1950s and 1960s, challenge existing power hierarchies. Feminists have used the criminal law to challenge male privilege by demanding penal sanctions for those who use violence against women in intimate relationships. The discourse of human rights has been deployed by indigenous peoples, women, victims of war atrocities, prisoners of war, and many other groups to claim protection from state authorities. Thus, law usually reinforces existing power arrangements, but can provide an avenue of resistance through its institutions and the discourse of rights.

Attention to the way that legal forms and institutions exercise and legitimate power, while offering a mode of resistance, leads to concerns with the way that laws are produced and enforced as well as with the linguistic and social exchanges that take place in courtrooms, police stations, and lawyers' offices (e.g., Conley and O'Barr, 1990). Increasingly, anthropologists have examined the technologies and forms of law itself. Rosemary Coombe (1998) analyzes the regime of international property law to reveal the underlying conceptions of individualism and agency implicit within these laws. She documents how, as Canadian First Nations engage with the language of intellectual property laws to contest the 'cultural appropriation' of native knowledge and symbols, they also resist its underlying possessive individualism. Indigenous groups deploy a 'double-voiced rhetoric,' whereby "they empty tropes of a dominant language simultaneously engaging and subverting these metaphors through the character of the alternative claims they make into the voice of an authorial other" (1998, p. 242).

Another approach to understanding law and power integrates insights from Science and Technology Studies to examine the content, form, and agents involved in the production of legality as a technology and network. This approach does not focus directly on the relations of power that underlie law-making processes. Instead, it shows how technologies of law, in the form of doctrine, interpretive techniques, or dispute resolution tools, produce forms of knowledge that conceal more substantive, political issues. Both Bruno Latour (2010), in his study of the French Conseil d'État, and Annelise Riles (2001), in her study of Fijian activists negotiating human rights language for the United Nations Fourth World Conference on Women in 1995, seek to open up the 'black box' of law. This is Latour's term for complex techniques that scientists present in diagrams as taken for granted rather than present in detail. Latour and Riles both analyze the details of legal processes to show how technologies of lawmaking become tools to overcome political and epistemological limits. Whether studying the objectivity of judges or the use of 'bracketing' as a way to move past substantive disputes in the United Nations, each of these technologies produces knowledge that is translated into commonplace understandings. Similarly, Merry (2011) examines new tools of international governance, such as the use of quantitative indicators to measure qualitative categories such as 'the rule of law,' as technologies that transform political decisions into scientific, empirical knowledge (see also Davis et al., 2012).

Scholars have also looked to the way that law imposes new forms of power through constructing and transforming notions of space. Drawing on the work of cultural geographers, these studies recognize space as a key constituent of social life that plays an important role in the construction of social relationships and the formation of the political domain. Since law is the apparatus through which states define political territories, as well as their domestic and public spheres, it is a key form through which space is made (see Law and Geography). BendaBeckmann et al. (2009) explore the relationship between competing spatial configurations of law within plural legal orders. By exploring the plural legal orders and their particular notions of space, they argue that "multiple legal constructions of space open up multiple arenas for the exercise of political authority, the localization of rights and 
obligations, as well as the creation of social relationships and institutions that are characterized by different degrees of abstraction, different temporalities and moral connotations" (2009, p. 4)

\section{Legal Consciousness and Identity}

Anthropologists have investigated the relationship between law and power in the construction of personhood and subjectivity. Law constitutes social identities and understandings of social relationships through its regulations and through the spectacular as well as the mundane processes of arrest, trial, and mediation through which these regulations are enforced and failure to comply is punished. Even when laws do not impinge directly on social life, they exercise power by shaping individuals' legal consciousness. This refers to the way in which people see themselves defined by and within law, the rights they can assert, and their entitlement to seek legal remedies for grievances in studies of legal consciousness, anthropologists use disputes to investigate these matters. These studies approach disputing as "a contest over meanings in which the law provides one possible set of meanings. The process of disputing is one of quarreling over interpretations of social relationships and events" (Merry, 1990, p. 6). Studies of legal consciousness illuminate the way that everyday understandings of law become important factors in the development of 'community' and social relations. Merry's work on working-class, urban legal consciousness showed how law becomes a means for challenging hierarchies of power and asserting privacy in opposition to social conflicts or constraints engendered by other forms of informal ordering. Similarly, in a collaborative effort to investigate the role of law in three American towns, Carol Greenhouse et al. (1994) suggest that law is a social practice that constructs the meaning of 'community' by defining 'insiders' and 'outsiders.' Exploring the reasons for litigation within their three respective sites of study, the authors found that law was either interpreted as a sign of difference and 'outsider' status, or as a form of 'insider' status by those seeking to defend the 'community.' Hence, they use the disputing approach to demonstrate the important role that law plays in constituting notions of community.

More recent studies of legal consciousness by scholars in other disciplines explore how people perceive injustice, understand themselves as rights-bearing subjects, and develop their identity based on new rights. Ewick and Silbey (1998) describe the schemas, or positional stances, that individuals develop to understand their relationship to the law. Laura BethNielsen's (2000) research examines the everyday attitudes and understandings of law as a way of dealing with sexual harassment. David Engel and Frank Munger (2003) analyze how the disability rights movement constructs identities around what it means to be disabled and when and why disabled people mobilize these rights. David Engel and Jaruwan Engel (2010) document a surprising shift in legal consciousness concerning personal injury cases in Thailand as ordinary people turn away from the law.

Anthropologists have also focused on the way in which legal ideologies constitute conceptions of subjectivity that shape identity claims and understandings of the self. Law participates in the construction of identity by soliciting specific expressions of difference. By constraining the types of claims that can be made, Collier et al. (1996) contend that the law sanctions particular types of identity making. Rather than recognizing all difference as socially produced, they suggest that legal mechanisms recognize only those claims that translate their identity into 'natural' categories. Thus, formal legal mechanisms do not recognize the types of difference that law itself has produced. This is a contradiction that anthropologists have documented as groups seek remedies for state and social discrimination by state courts. For example, James Clifford (1988) describes how the Mashpee struggled for recognition as a 'tribe' under the Non-Intercourse Act in the United States. In this case, the court became a site to adjudicate a group's collective sense of identity based on legal categories rather than the self-understanding of the community.

Land claims have proved a particularly important site for anthropologists to investigate the relationship between identity and law. Elizabeth Povinelli (2002) describes how aboriginal land claims in Australia require authentic indigenous subjects who are "called on to perform an authentic difference in exchange for the good feelings of the nation and the reparative legislation of the state $^{\prime \prime}$ (2002, p. 6). Yet there is an inherent contradiction, a 'cunning of recognition,' in that as the state recognizes aboriginal people and difference more broadly, it defines what constitutes an appropriate form of difference. People and groups must therefore represent themselves through these categories in order to win recognition of their legal rights. This, the process of recognition, extends the reach of liberal legalism. Jan French's study of Brazil (2009) shows how recognized categories of indigenity alter the lived experiences of people who adopt legally recognized categories for identity, reshaping their social relationships and claims to land.

The intersections between law and identity are increasingly central issues in the anthropology of law. Law constrains and limits identity claims by granting or denying citizenship to people who travel across transnational boundaries. The complex relationship that ensues when the law seeks to erase past forms of identification and construct new relationships to the state via identity is the focus for Susan Coutin's (2000, 2003) and Barbara Yngvesson's (2010) works, but in different contexts. Coutin's research on Guatemalan and Salvadoran immigrants to the United States and Yngvesson's research on transnational adoption both explore the ways in which adoptees and immigrants must reconcile forms of identity no longer recognized by law. These authors show the power and authority of law as an epistemological regime that confers particular forms of 'truth' to individuals in the process of self-making. Not only does law define identity, as Yngvesson (2006) and Coutin (2000) and both together (Coutin and Yngvesson, 2008; Yngvesson and Coutin, 2008) demonstrate, but also, as borders shift, identities can change even as people remain in place. Tobias Kelly's $(2004,2006)$ analysis of residents of the West Bank in Palestine illustrates this phenomenon vividly. With the development of research on legal consciousness, the relationships among legal culture, legal consciousness, and legal identity are increasingly complicated and overlapping, requiring clear definitions of terms (Merry, 2012). 


\section{Legal Pluralism}

In the contemporary world, societies typically have more than one legal system. Legal pluralism refers to situations of legal coexistence in a single social field (Merry, 1988). Initially described in colonial situations, in which the colonial power superimposed a European legal system over an existing indigenous system, legal pluralism is now understood as a fundamental characteristic of all legal systems. Early insights into legal pluralism within advanced capitalist states were drawn from Sally Falk Moore's (1978) description of semiautonomous social fields, domains of social life that are self-regulated but also subject to larger forms of regulation, such as commercial networks or criminal communities. Legal pluralism has since been used to understand the multiple layers of regulation developed out of both private and public forms of governance. For example, many institutions such as schools and corporations develop forms of private governance. Informal but rule-governed relationships are also characteristic of families, communities, and voluntary organizations, although there is considerable debate about whether such forms of normative ordering should be called law. The term 'interlegality' emphasizes the interactions among multiple legal orderings (De Sousa Santos, 1987).

Early descriptions of plural legal systems examined each in isolation, but more recent work emphasizes the way that plural systems shape one another. Typically, plural legal systems are shaped by differing relations of power. In colonial situations, the colonial authority often established one legal system for the subjugated and another for the colonial authorities (Moore, 1986; Merry, 2000). However, as anthropologists examine postcolonial and contemporary international forms of governance, they focus on interactions among legal systems and their impact on litigants and on each other. For example, Richard Wilson's study of the South African Truth and Reconciliation Commission argues that the plural legal systems in South Africa represent different forms of authority and approaches to dealing with past injuries. Taking a processual approach, he suggests that studies of legal pluralism should focus on the way that the state and other actors seek to legitimate legal orders within the broader context of state formation and resistance (Wilson, 2001).

Globalization increases legal pluralism in two ways. First, it fosters the circulation of legal forms and practices from one nation-state to another. Constitutions, codes, and legal institutions are commonly transplanted, much as they were during the earlier period of colonialism. These transplants introduce codes and procedures quite different from those of the receiving society, often with the intention of reform. Colonial transplants characteristically were phrased as furthering civilization, mid-twentieth-century transplants as modernizing institutions, and late twentieth-century ones as promoting democracy and the rule of law. Ugo Mattei and Laura Nader (2008) argue that in the post-Cold War era, the 'rule of law' has been promoted as a nonpolitical, nondistributive technology that lacks the institutional virtues of democracy promotion that were central to efforts of Third World development during the Cold War. As such, the export of rule of law, they argue, has been a proxy for privatization and neoliberalization.
The growing field of 'transitional justice,' which refers to the wide array of processes and formal mechanisms that states establish to deal with past mass human rights violations, constitutes another form of legal pluralism. Transitional justice processes seek to reconstitute the state and restore the rule of law as a necessary precondition for democratic transition. Over the last two decades, several formalized approaches to transitional justice have been created. These approaches include criminal prosecutions, truth commissions, reparations, lustration, and memorialization. In theory, these approaches are complementary. States may choose to apply multiple approaches at one time, or may use several approaches successively. These approaches are used in a wide variety of political environments ranging from military dictatorships to ethnic civil wars. The field of transitional justice has engendered a large cadre of professionals who do this work around the world.

Considerable anthropological research in the field of human rights and transitional justice focuses on the way these global justice systems operate in practice. Anthropologists tend to link local ethnographic research with examinations of the global institutions promoting human rights and international justice. Mark Goodale (2009) explores the history of anthropology's engagement with human rights, while Hinton and $\mathrm{O}^{\prime} \mathrm{Neill}$ (2009) offer a series of anthropological perspectives on the way that local communities in many parts of the world experience transitional justice in response to genocide. Harri Englund's (2006) study of the way that human rights are understood and used in Malawi provides valuable insights into the difficulties of translating and implementing human rights in situations of autocracy and political opposition. Kimberly Theidon (2012) examines the workings of the Peruvian Truth and Reconciliation Commission from the perspective of highland Peruvians who suffered from the violence of the period of struggles between the Shining Path and government soldiers. Kamari Clarke's (2009) analysis of the International Criminal Court takes a local as well as a global perspective on the kinds of justice that this new international regime provides, suggesting that its local practice differs from its global aspirations. Ethnographic studies of the meanings of human rights in local communities show that they are one discourse among many, and often not the dominant one. For example, Daniel Goldstein (2012) shows how concerns about security take precedence over human rights in a poor urban neighborhood in Bolivia.

Secondly, globalization increases legal pluralism by constructing a global legal order that exists outside state law. As international law and international organizations expand, legal pluralism provides a valuable analytical framework for understanding this broadening range of legal forms. The human rights system, made up of rules and sanctioning systems embedded in international institutions such as the United Nations, is a central facet of the new global legal order (see Human Rights, Anthropology of). Although the human rights system is a multilateral treaty regime built on a system of sovereign states, it is redefining the nature of state sovereignty itself. Pressure for compliance with human rights by states and transnational nongovernmental organizations is circumscribing state sovereignty to some extent. At the same time, 
domestic actors such as indigenous peoples seek to constrain state sovereignty as they make claims for legal and political autonomy using international principles of self-determination and rights to protection of culture.

Anthropological research explores the processes by which human rights categories are constructed. For example, Tobias Kelly (2011) examines a series of settings in which legal institutions determine whether or not a person has been tortured as a way of understanding what torture means. He shows that the category is constructed through social processes rather than through a preexisting definition. Richard Wilson (2011) takes a similar approach in his analysis of the way in which international criminal tribunals generate historical accounts of war crimes and genocide by looking closely at the operation of the International Criminal Court.

Another form of transnational law that legal pluralism has been used to understand is the expanding field of international commercial law, which includes a wide range of mechanisms from formal treaties to informal law based on nonbinding agreements to corporate self-governance. Finally, the creation of new regional legal entities such as the European Union is also exploding the autonomy of local legal orders (DarianSmith, 1999).

As anthropologists turn their attention to these transnational legal orders, they have expanded and further developed ethnographic methods to analyze intersecting legal orders on multiple scales through 'multisited' ethnography (Marcus, 1995; Merry, 2006b). Multisited ethnography, including sites that are vertically connected local and global spaces, enables anthropologists to explore the many ways in which both separate legal orders and the 'local' and 'global' are not opposing entities, but rather mutually constitutive social fields.

\section{Conclusion}

The anthropology of law changed dramatically over the twentieth century. While earlier theories saw law as a structural feature of a whole society and used it to classify societies, more recent anthropological studies examine dispute processing, the linguistic and cultural features of legal settings that shape the way power is exercised, and the extent to which legal categories and concepts are embedded in individual consciousness and local culture. At the same time, the notion of culture as an integrated, homogeneous, and consensual system has been replaced by models of law in society that focus on the multiple and contradictory nature of rules and procedures. Contests among these systems of power and symbolism account for social change. Some of the competing frameworks are the product of alternative systems of legal regulation developed through colonialism or globalization. Contemporary legal anthropology views law as the product of contestation about meanings and identities in social fields constituted by multiple legalities. It examines the way that law exercises power and sees this process as mediated by legal procedures, linguistic forms and exchanges, and cultural practices that shape legal settings and provide individuals with access to these settings.
See also: Colonialism, Anthropology of; Human Rights,

Anthropology of; Law and Geography; Law and Society:

Development of the Field; Legal Culture and Legal

Consciousness; Science and Technology, Anthropology of.

\section{Bibliography}

Benda-Beckmann, F.V., Benda-Beckmann, K. von, Griffiths, Anne (Eds.), 2009. Spatializing Law: An Anthropological Geography of Law in Society. Ashgate Publishing Ltd.

Clarke, K.M., 2009. Fictions of Justice: The International Criminal Court and the Challenges of Legal Pluralism in Sub-Saharan Africa. Cambridge University Press

Clifford, J., 1988. The Predicament of Culture: Twentieth-Century Ethnography, Literature, and Art. Harvard University Press.

Collier, J.F., 1973. Law and Social Change in Zinacantan. Stanford University Press.

Collier, J.F., Maurer, B., Suarez-Navaz, L., 1996. Sanctioned identities: legal constructions of modern personhood. Identities: Global Studies in Culture and Power 2, 1-27.

Comaroff, J.L., Roberts, S., 1981. Rules and Processes. University of Chicago Press.

Conley, J.M., O'Barr, W.M., 1990. Rules versus Relationships: The Ethnography of Legal Discourse. University of Chicago Press.

Conley, J.M., O'Barr, W.M., 2005. Just Words: Law, Language, and Power. University of Chicago Press.

Coombe, R.J., 1998. The Cultural Life of Intellectual Properties: Authorship, Appropriation, and the Law. Duke University Press, Durham.

Coutin, S., Yngvesson, B., 2008. Technologies of knowledge production: law, ethnography, and the limits of explanation. PoLAR: Political and Legal Anthropology Review 31, 1-7.

Coutin, S.B., 2000. Denationalization, inclusion, and exclusion: negotiating the boundaries of belonging. Indiana Journal of Global Legal Studies 7, 585-593.

Coutin, S.B., 2003. Legalizing Moves: Salvadoran Immigrants' Struggle for U.S. Residency. University of Michigan Press.

Darian-Smith, E., 1999. Bridging Divides: The Channel Tunnel and English Legal Identity in the New Europe. University of California Press.

Davis, K.E., Kingsbury, B., Merry, S.E., 2012. Indicators as a technology of global governance. Law and Society Review 46, 71-104.

Engel, D.M., Munger, F.W., 2003. Rights of Inclusion: Law and Identity in the Life Stories of Americans with Disabilities. University of Chicago Press.

Engel, D.M., Engel, Jaruwan S., 2010. Tort, Custom, and Karma: Globalization and Legal Consciousness in Thailand. Stanford Law Books.

Englund, H., 2006. Prisoners of Freedom: Human Rights and the African Poor. University of California Press.

Ewick, P., Silbey, S.S., 1998. The Common Place of Law. University of Chicago Press, Stories From Everyday Life.

French, J.H., 2009. Legalizing Identities: Becoming Black or Indian in Brazil's Northeast. University of North Carolina Press.

Geertz, C., 1983. Local Knowledge: Further Essays in Interpretive Anthropology. Basic Books.

Gluckman, M., 1973. The Judicial Process among the Barotse of Northern Rhodesia (Zambia). Manchester University Press.

Goldstein, D.M., 2012. Outlawed: Between Security and Rights in a Bolivian City. Duke University Press.

Goodale, M., 2009. Surrendering to Utopia: An Anthropology of Human Rights. Stanford University Press.

Greenhouse, C.J., Yngvesson, B., Engel, D.M., 1994. Law and Community in Three American Towns. Cornell University Press.

Hinton, A.L., O'Neill, K.L. (Eds.), 2009. Genocide: Truth, Memory, and Representation. Duke University Press.

Hastrup, K., 2003. Representing the common good: the limits of legal language. In: Anthropological Studies of Rights, Claims and Entitlements. Psychology Press.

Hoebel, E.A. ((1954) 2006). The Law of Primitive Man: A Study in Comparative Legal Dynamics. Harvard University Press.

Humphreys, S., 1985. Law as discourse. History and Anthropology 1, 239-264.

Kelly, T., 2004. Returning home? Law, violence, and displacement among West Bank Palestinians. PoLAR: Political and Legal Anthropology Review 27, 95-112.

Kelly, T., 2006. Law, Violence and Sovereignty among West Bank Palestinians. Cambridge University Press. 
Kelly, T., 2011. This Side of Silence: Human Rights, Torture, and the Recognition of Cruelty. University of Pennsylvania Press.

Latour, B., 2010. The Making of Law: An Ethnography of the Conseil d'État. Polity. Lazarus-Black, M., Hirsch, S.F. (Eds.), 1994. Contested States: Law, Hegemony and Resistance. Routledge.

Llewellyn, K.N., Hoebel, E.A., (1941(2000)). The Cheyenne Way: Conflict and Case Law in Primitive Jurisprudence. Wm S. Hein Publishing.

Maine, H.S., (1861(2007)). Ancient Law: Its Connection to the History of Early Society.

Malinowski, B., 1926. Crime and Custom in Savage Society. Rowman \& Littlefield.

Marcus, G.E., 1995. Ethnography in/of the world system: the emergence of multi-sited ethnography. Annual Review of Anthropology 24, 95-117.

Mattei, U., Nader, L., 2008. Plunder: When the Rule of Law Is Illegal. John Wiley \& Sons.

Merry, S.E., 1988. Legal pluralism. Law and Society Review 22, 869-896.

Merry, S.E., 1990. Getting Justice and Getting Even: Legal Consciousness among Working-Class Americans. University of Chicago Press, Chicago.

Merry, S.E., 2000. Colonizing Hawai'i: The Cultural Power of Law. Princeton University Press.

Merry, S.E., 2006a. Human Rights and Gender Violence. University of Chicago Press.

Merry, S.E., 2006b. Transnational human rights and local activism: mapping the middle. American Anthropologist 108, 38-51.

Merry, S.E., 2011. Measuring the world: indicators, human rights, and global governance. In: Damani, Partridge, Marina, Welker, Rebecca, Hardin (Eds.), Corporate Lives: New Perspectives on the Social Life of the Corporate Form. Current Anthropology, vol. 52. Wenner-Gren Symposium Series, pp. S83-S95 (Suppl. Issue 3).

Merry, S.E., 2012. What is legal culture? An anthropological perspective. Journal of Comparative Law 5 (2), 40-58.

Mertz, E., 2007. The Language of Law School: Learning to "Think Like a Lawyer". Oxford University Press.

Moore, S.F., 1973. Law and social change: the semi-autonomous social field as an appropriate subject of study. Law and Society Review 7, 719.

Moore, S.F., 1978. Law as Process: An Anthropological Approach. Routledge \& Kegan Paul, London.

Moore, S.F., 1986. Social Facts and Fabrications: Customary Law on Kilimanjaro, 1880-1980. Cambridge University Press, Cambridge.
Nader, L., 1991. Harmony Ideology: Justice and Control in a Zapotec Mountain Village. Stanford University Press.

Nader, L., 1997. Law in Culture and Society. University of California Press.

Nader, L., Todd, H.F. (Eds.), 1978. The Disputing Process: Law in Ten Societies. Columbia University Press.

Nielsen, L.B., 2000. Situating legal consciousness: experiences and attitudes of ordinary citizens about law and street harassment. Law and Society Review $34,1055$.

Povinelli, E.A., 2002. The Cunning of Recognition: Indigenous Alterities and the Making of Australian Multiculturalism. Duke University Press.

Radcliffe-Brown, A., 1933. Law, primitive. In: Encyclopedia of the Social Sciences, vol. 9, pp. 202-206.

Richland, J.B., 2008. Arguing with Tradition: The Language of Law in Hopi Tribal Court. University of Chicago Press.

Riles, A., 2001. The Network Inside Out. University of Michigan Press.

Rosen, L., 1989. The Anthropology of Justice: Law as Culture in Islamic Society. Cambridge University Press.

Santos, B., de, S., 1987. Law: a map of misreading - toward a postmodern conception of law. Journal of Law and Society 14, 279.

Starr, J., Collier, J.F., 1989. History and Power in the Study of Law: New Directions in Legal Anthropology. Cornell University Press.

Theidon, K., 2012. Intimate Enemies: Violence and Reconciliation in Peru. University of Pennsylvania Press.

Wilson, R., 2001. The Politics of Truth and Reconciliation in South Africa: Legitimizing the Post-Apartheid State. Cambridge University Press, Cambridge, New York.

Wilson, R.A., 2011. Writing History in International Criminal Trials. Cambridge University Press.

Yngvesson, B., 2006. Backed by papers: undoing persons, histories, and return. American Ethnologist 33, 177-190.

Yngvesson, B., 2010. Belonging in an Adopted World: Race, Identity, and Transnational Adoption. University of Chicago Press.

Yngvesson, B., Coutin, S., 2008. Schrödinger's cat and the ethnography of law. PoLAR: Political and Legal Anthropology Review 31, 61-78. 